B O N N E V I L L E P O W E R A D M I N I S T R A T I O

Deepwater Spawning of Fall Chinook Salmon (Oncorhynchus tshawytscha) near Ives and Pierce Island of the Columbia River

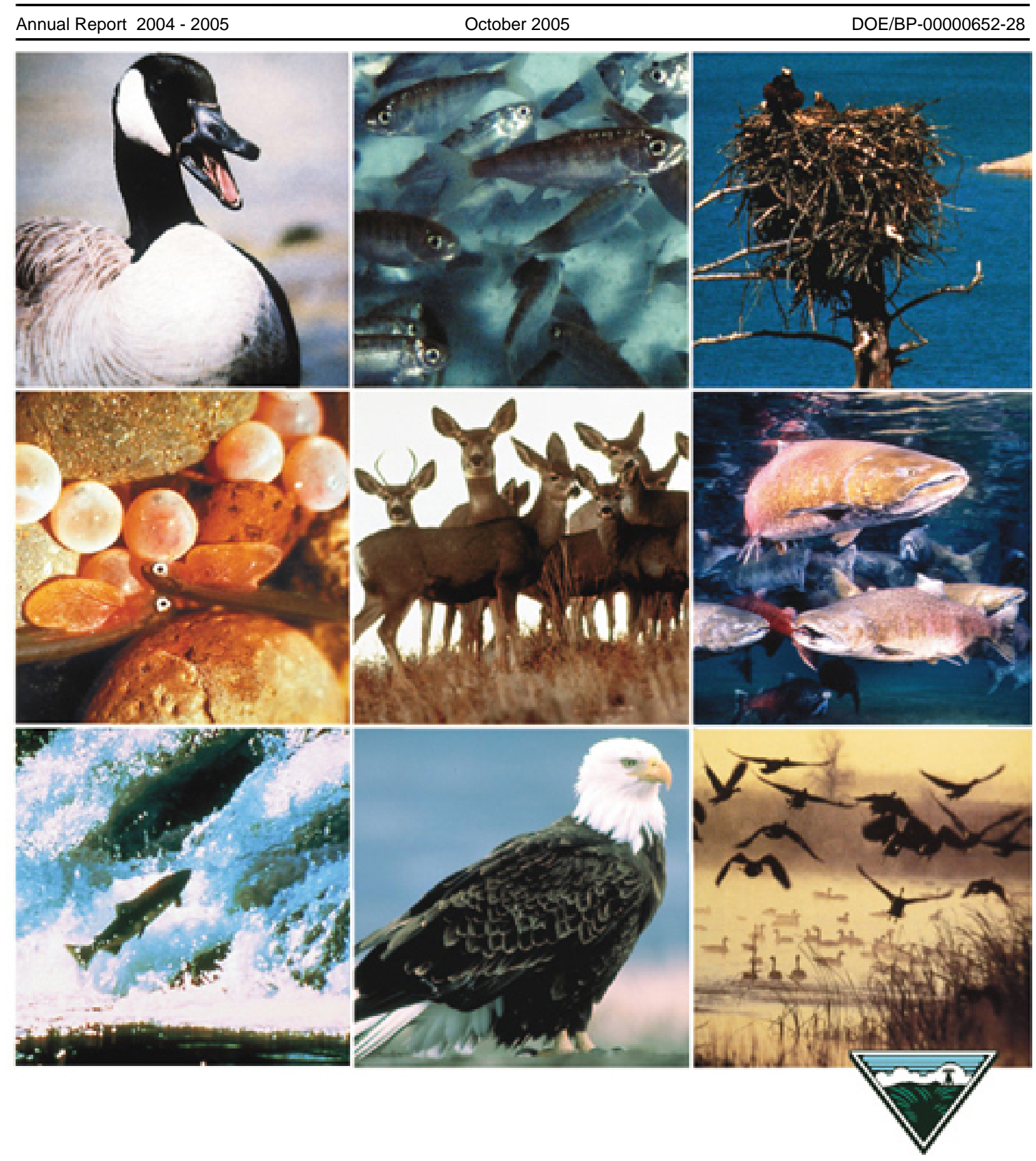


This Document should be cited as follows:

Mueller, Robert, "Deepwater Spawning of Fall Chinook Salmon (Oncorhynchus tshawytscha) near Ives and Pierce Island of the Columbia River", 2004-2005 Annual Report, Project No. 199900301, 26 electronic pages, (BPA Report DOE/BP-00000652-28)

Bonneville Power Administration

P.O. Box 3621

Portland, OR 97208

This report was funded by the Bonneville Power Administration (BPA), U.S. Department of Energy, as part of BPA's program to protect, mitigate, and enhance fish and wildlife affected by the development and operation of hydroelectric facilities on the Columbia River and its tributaries. The views in this report are the author's and do not necessarily represent the views of BPA. 


\title{
Deepwater Spawning of Fall Chinook Salmon (Oncorhynchus tshawytscha) near Ives and Pierce Island of the Columbia River, 2004
}

\author{
Annual Report \\ $2004-2005$ \\ Prepared by: \\ Robert P. Mueller \\ Pacific Northwest National Laboratory \\ Richland, WA 99352 \\ Prepared for: \\ U.S. Department of Energy \\ Bonneville Power Administration \\ Division of Fish and Wildlife \\ P.O. Box 3621 \\ Portland, OR 97208
}

Project No. 1999-00301

Contract No. 00000652

October 2005 


\section{Executive Summary}

Pacific Northwest National Laboratory conducted video-based boat surveys to identify fall Chinook salmon (Oncorhynchus tshawytscha) spawning areas located in deep water (greater than $1 \mathrm{~m}$ ) downstream of Bonneville Dam in fall 2004. This report documents the number and extent of Chinook salmon spawning near Ives and Pierce Islands of the Columbia River and is the sixth in a series of reports prepared since 1999. The main objectives of this study were to find deepwater spawning locations of fall Chinook salmon in the main Columbia River channel, collect additional data on physical habitat parameters at spawning sites, and provide estimates of adult spawners in the surveyed area. The primary search area was adjacent to the upper portion of Pierce Island, and the secondary search zone was downstream of this area near the lower portion of Pierce Island. A secondary objective was to document the occurrence of any chum salmon (O. keta) redds in the deeper sections downstream of Hamilton Creek (slough zone search area).

Fall Chinook salmon redd numbers were down slightly from the record number found during 2003. The number of fall Chinook redds found in the Ives-Pierce Island complex (river km 228.5) during 2004 was 293, which does not include the number of shallow water redds found by visual observation by boat by the Oregon Department of Fish and Wildlife. The redds encompassed an area of 14.6 ha occurring

adjacent to the lower part of Ives Island and Pierce Island. Peak spawning activity, based on redd counts and live fish seen near redds, was on or near November 16, 2004. An expanded redd count based on percentage video coverage in the primary and secondary search zones was 3,198 fall Chinook salmon redds at water depths exceeding approximately $1.0 \mathrm{~m}$ (approximately $125 \mathrm{kcfs}$ ) with an estimated spawning population of 10,800. Fall Chinook salmon redds were found at water depths from 1.07 to $7.6 \mathrm{~m}$ and were constructed predominantly of medium cobbles ranging in size from 7.6 to $15.2 \mathrm{~cm}$ in diameter. Near-bed water velocity readings taken in the secondary search ranged from 0.04 to $0.98 \mathrm{~m} / \mathrm{s}$ (median $0.45 \mathrm{~m} / \mathrm{s}$ ). No chum salmon redds were found in a limited area within the relatively deeper sections of Hamilton Slough below Hamilton Creek. No additional salmon or chum redds were found in other areas searched, including near Woodward, Tanner, and McCord Creeks. 


\section{Acknowledgments}

The author thanks Scott Titzler, Fenton Khan, Corey Duberstein, and Nate Phillips of Pacific Northwest National Laboratory for their assistance in conducting the surveys, preparing geographic information system maps, and analyzing the videotapes. 


\section{Contents}

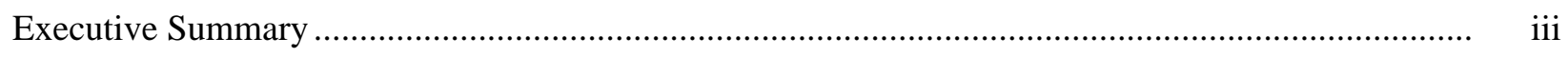

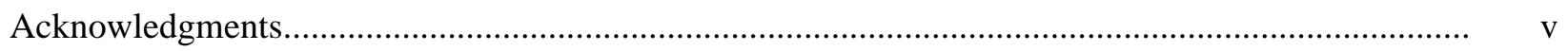

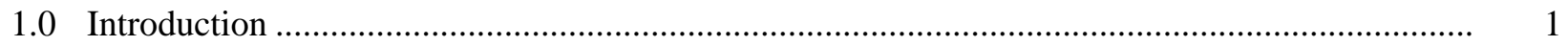

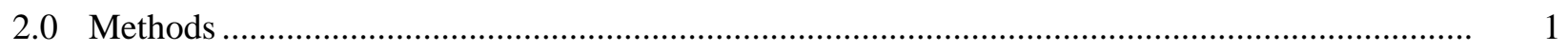

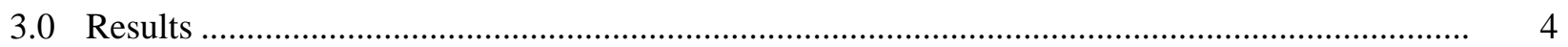

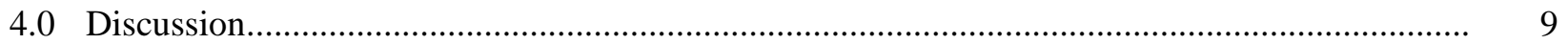

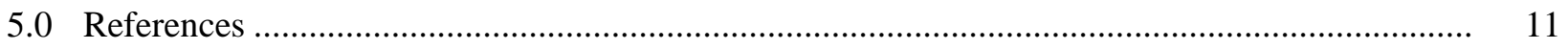

Appendix A - Near-Bed Velocity Point Measurements, 2004 ........................................................ A.1

Appendix B - Maps Illustrating Fall Chinook Salmon Redd Spawning Areas, 1999 Through 2003 ... B.1

\section{Figures}

1 Location of Search Zones in Relation to Ives and Pierce Islands ............................................... 2

2 Location of Fall Chinook and Chum Salmon Redds in the Mainstem of the Columbia River Below Bonneville Dam in 2004.

3 Distribution of Fall Chinook Salmon Redds Relative to Water Depth During the November and December 2004 Surveys in the Primary and Secondary Search Zones ................ 6

4 Dominant Substrate Classification of Fall Chinook Salmon Redds in the Primary and

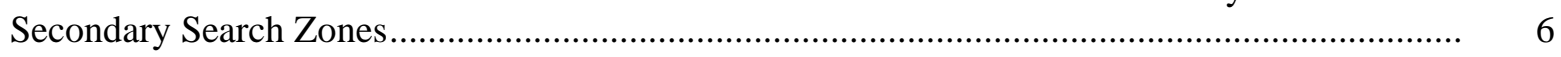

5 Substrate Composition Within the Fall Chinook Spawning Zones and Redds

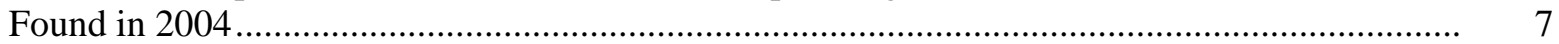

$6 \quad$ Fall Chinook Salmon Spawning Area for Redds Found During 2004 ....................................... 8

$7 \quad$ Near-Bed Water Velocity Measurements Taken December 9, 2004, and Redd

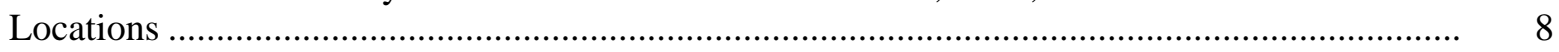

8 Historical Perspective of Redd Proportions in the Primary and Secondary Search Zones near Pierce Island, 2004.

\section{Tables}

1 Substrate Categories Used for Spawning Habitat Classification ............................................... 3

2 Average River Flow and Elevation Conditions Recorded During the Underwater Video

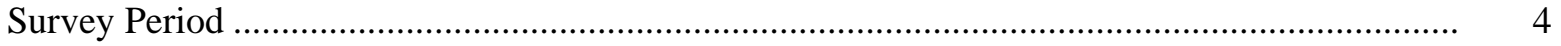

3 Number of Fall Chinook Redds Found in Primary and Secondary Search Zones 2004............... 4

$4 \quad$ Estimated Number of Fall Chinook Salmon Redds Occurring in the Primary Search and Secondary Zone near Ives and Pierce Islands near the Peak Spawning Period, November 22 and 23, 2004

$5 \quad$ Fall Chinook Redd Counts and Approximate Spawning Areas from 1999 Through 2004 near Ives and Pierce Islands. 


\subsection{Introduction}

Since 1993, fall Chinook salmon (Oncorhynchus tshawytscha) have used Ives and Pierce Islands downstream of Bonneville Dam for spawning (Hymer 1997). Two stocks of fall Chinook salmon spawn in the area-lower river or Tule, currently listed as threatened (U.S. Fish and Wildlife Service 1999), and upriver bright stock, most of which spawn in the Hanford Reach of the Columbia River (Huntington et al. 1996). The size of this population was estimated at 1,800 to 5,200 fish from 1994 to 1996 (Hymer 1997). More recently, an adult population of 1,881 adult fish was estimated in 2002 (van der Naald et al. 2004) and 1,533 in 2003 (van der Naald et al. 2005). These estimates are based on carcass tagging and recoveries near shallow water and do not take into account fish that spawn nearer the main river channel in water depth exceeding approximately $2 \mathrm{~m}$.

Pacific Northwest National Laboratory (PNNL) ${ }^{1}$ has conducted underwater video surveys from 1999 through 2004 downstream of Bonneville Dam. The primary objectives in 2004 were to locate and map deepwater (greater than $1 \mathrm{~m}$ ) spawning areas of fall Chinook salmon near the main Columbia River channel and to collect additional data on the physical habitat at spawning sites. The secondary objective was to map any chum salmon (O. keta) redds located in deeper sections in and around Ives and Pierce Islands.

\subsection{Methods}

The survey area consisted of three different search zones approximately $3.5 \mathrm{~km}$ downstream of Bonneville Dam near river $\mathrm{km} 228.5$. The primary zone $\left(125,000 \mathrm{~m}^{2}\right)$ along the main channel side of Pierce Island was segmented into regularly spaced transects, $20 \mathrm{~m}$ apart and $160 \mathrm{~m}$ long (37 total), running perpendicular to the shoreline. An additional eight transects were run at $20-\mathrm{m}$ spacing immediately upstream of the primary zone during the 2003 surveys. The secondary zone $\left(60,350 \mathrm{~m}^{2}\right)$ was at the lower end of Pierce Island and consisted of 18 additional transects, $25 \mathrm{~m}$ apart and $120 \mathrm{~m}$ long. The third search zone (slough area) consisted of two separate areas. The first was at the lower end of Pierce Island, and the second was within Hamilton Slough between Ives and Pierce Islands (Figure 1). These areas were established based on previous surveys that documented fall Chinook and chum salmon redd occurrences (Mueller and Dauble 2000; Mueller 2001, 2002, 2003, 2004).

Two separate underwater video boat surveys were conducted in late November and early December 2004. The surveys were conducted just after November 16, the peak spawning date for fall Chinook salmon. This date was based on visual observations of adult fish by the Oregon Department of Fish and Wildlife (ODFW).

The boat-deployed video system consisted of a high-sensitivity remote camera (DeepSea MultiSeaCam ${ }^{\circledR}$ Model 1050) attached to a weighted platform or sled. The camera was positioned at a slight angle forward from vertical so that redd characteristics (bed elevation) could be detected more easily. Recordings were made using an 8-mm digital recorder (Sony Model GVD 7000) situated on the survey vessel; two high-resolution monitors for real-time viewing of the video obtained by the remote camera

\footnotetext{
${ }^{1}$ Pacific Northwest National Laboratory is a multiprogram national laboratory operated by Battelle for the U.S. Department of Energy.
} 
also were aboard the survey vessel. An integrated video/tow cable attached to a manual winch with slip ring mechanisms was used to raise and lower the sled to the desired depth. The presence of disturbed cobble indicated by changes in background contrast as well as "tail-spill" piles were the primary criteria used to determine spawning activity.

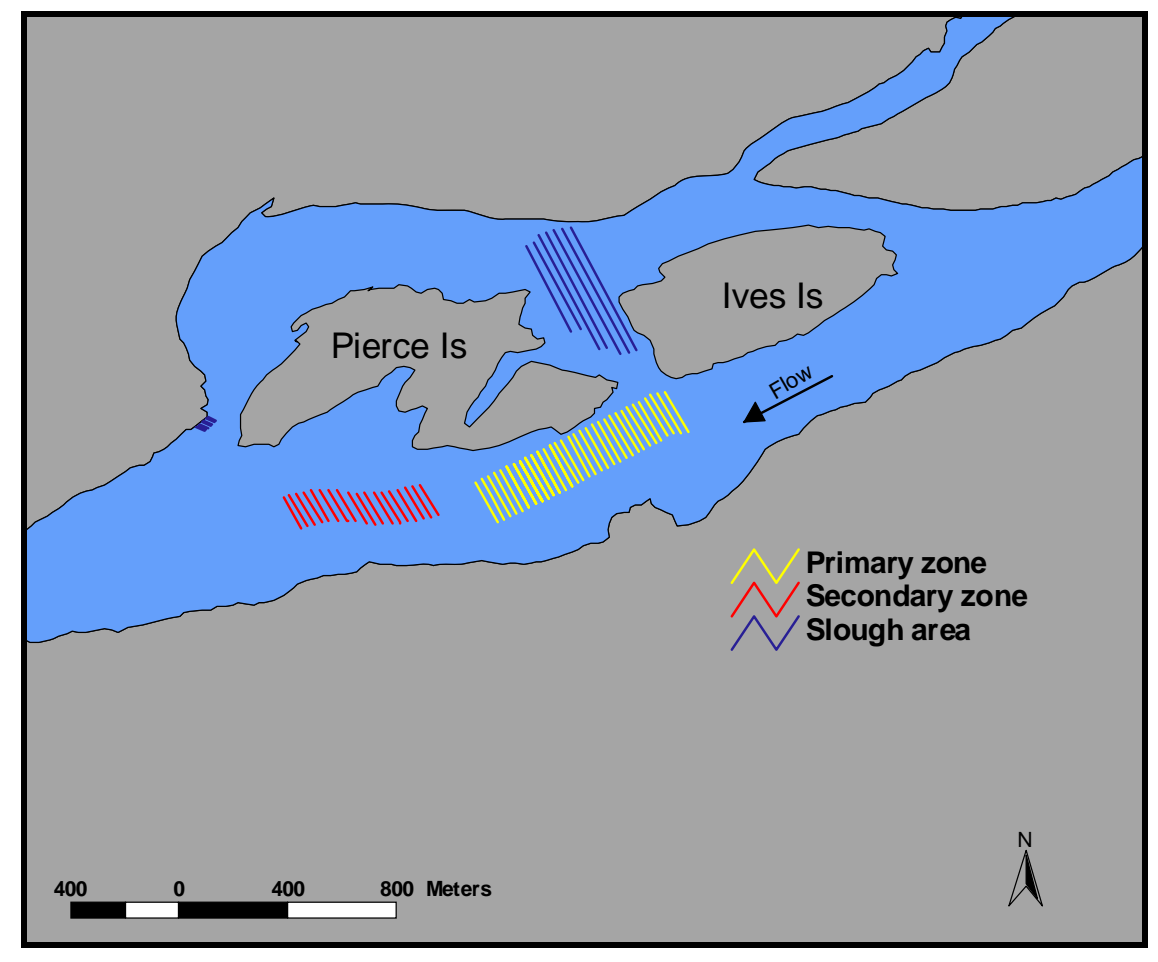

Figure 1. Location of Search Zones in Relation to Ives and Pierce Islands

The coverage area varied throughout the survey period and was influenced by ambient light levels, water clarity, boat speed, and, to a lesser extent, bottom slope and composition. The distance from the camera lens to the substratum averaged approximately $1.2 \mathrm{~m}$, providing an effective coverage area of approximately $2.5 \mathrm{~m}^{2}$ at any one location along each transect. The approximate vertical coverage along each transect was $1.2 \mathrm{~m}$.

An on-board, real-time differential global positioning system (DGPS) (Trimble Pathfinder ${ }^{\circledR}$ Pro XR) was used to collect positional data and to navigate on preset transect grids during the surveys. The integrated DGPS beacon receiver and antenna provided DGPS corrections to calculate accuracy to below approximately $0.5 \mathrm{~m}$. The system software (ASPEN) displayed a background map of the study site on a personal computer so that researchers could navigate to site locations on a predetermined transect line and visually verify data accuracy in the field. Both the DGPS and video system were synchronized via a time stamp. When a redd was encountered, the time was noted in the logbook; the notation was later associated with a GPS position. Further analysis and verification of redds was performed at PNNL in Richland, Washington. The location of any new redds also was mapped to an Arc/View ${ }^{\circledR}$ geographic information system (GIS).

The type and size of the substratum were determined with underwater red lasers (C-Map Systems Model HL6312G). The lasers provided a reference scale within the camera image. The distance from the 
camera lens to the substratum ranged from 0.9 to $1.4 \mathrm{~m}$, providing an effective view path of approximately $2.5 \mathrm{~m}^{2}$ along each transect. Grain size was determined by digitizing the image when the camera was positioned near the center portion of the redd and processing the image using an imaging software program (Optimas ${ }^{\circledR}$ ). Three rocks were measured (long axis diameter) that constituted the dominant substrate size for each digitized image. An average of the three measurements was used to determine the actual substrate category for each redd. The substrate size for each redd was classified according to five general size categories (Table 1). Using the substrate category, we expanded these points, based on association with the nearest substrate type, to predict the substrate category where no data points were collected. We projected the GPS positions into the GIS (ArcView) and then used a script (Thiessen Polygons) to connect a series of point locations with line segments, erecting perpendiculars to those line segments at their midpoints, and then extending those perpendiculars until they intersected.

Table 1. Substrate Categories Used for Spawning Habitat Classification (modified from Platts et al. 1983)

\begin{tabular}{||c|l|c||}
\hline Category & \multicolumn{1}{|c||}{ Sediment Classification } & $\begin{array}{c}\text { Long Axis Diameter of Individual } \\
\text { Substrate (cm) }\end{array}$ \\
\hline \hline 1 & Fines, silt & $<0.61$ \\
\hline 2 & Gravel & $0.6-7.6$ \\
\hline 3 & Medium cobble & $7.6-15.2$ \\
\hline 4 & Large cobble & $15.2-30.5$ \\
\hline 5 & Boulder & $>30.5$ \\
\hline
\end{tabular}

Near-bed water velocity point measurements were obtained with a Marsh-McBirney Flo-Mate flowmeter (Model 2000) positioned 20 to $22 \mathrm{~cm}$ above the substratum, with the weighted platform resting on the river bottom. A measurement was recorded after the display stabilized. Point velocities were measured throughout the secondary survey zone, approximately four measurements per transect (Appendix A). GIS maps were created using Thiessen Polygons to connect the point velocity locations with line segments, erecting perpendiculars to those line segments at their midpoints, and then extending those perpendiculars until they intersected. Mean near-bed velocities ranging from 0.1 to $2.0 \mathrm{~m} / \mathrm{s}$ are considered to be favorable for fall Chinook salmon spawning activity (Groves and Chandler 1999).

To eliminate the possibility of counting a redd more than once during the two survey periods, we omitted any redds that fell within a 1.8-m radius of a nearby redd. This distance was based on an overall redd size of $10 \mathrm{~m}^{2}$, which is indicative of fall Chinook salmon redds within the Columbia River (Burner 1951; Chapman et al. 1983; Visser 2000). In addition, the cumulative number of redds found during both survey periods was extrapolated to estimate the total number of redds constructed within the primary search zone. These estimates were calculated by taking the total number of redds found during each of the surveys and expanding this number based on the percentage of coverage (assuming normal distribution) within the total search zone. The total fall Chinook salmon redd estimates do not include redds found by other researchers conducting visual redd observations by boat.

Water turbidity was recorded using a LaMotte turbidimeter (Model 2008). Recorded tapes were reviewed in detail at the PNNL computer laboratory using a high-resolution monitor. Bathymetric data were obtained using a one-dimensional, unsteady river flow and water quality computer model, MASS1 (Modular Aquatic Simulation System 1D), developed at PNNL. 


\subsection{Results}

A total of 293 fall Chinook salmon redds were found and mapped during surveys conducted in November and December 2004 (Figure 1). Initial deepwater redd surveys of the main channel near Ives and Pierce Islands were completed on November 22 and 24, 2004, shortly after the peak spawning date of November 16 for fall Chinook salmon (FPC 2004). River flows recorded at Bonneville Dam were quite variable, ranging from 121 to $170 \mathrm{kcfs}$ (Table 2). The majority of the redds were mapped on November 22 and 23 when flows averaged 126.1 kcfs. A total of 193 fall Chinook redds were located and mapped within all surveys zones. This total includes 124 within the primary search zone, 63 in the secondary zone, and 6 additional redds found upstream of the primary search zone near the lower portion of Ives Island (Table 3). A separate survey was conducted in the slough zone downstream of Hamilton Creek. A total of seven transects were run within this zone, with water depths ranging from 0.6 to $2.7 \mathrm{~m}$. Flows during this survey were near $127 \mathrm{kcfs}$ (staff gage $1=0.98 \mathrm{ft}$ ), which precluded boat access in the area between Ives and Pierce Islands. Several chum carcasses were observed, but no confirmed redds were found during the limited search.

Table 2. Average River Flow and Elevation Conditions Recorded During the Underwater Video Survey Period

\begin{tabular}{||l|c|c||}
\hline \multicolumn{1}{|c|}{ Date } & $\begin{array}{c}\text { Discharge at Bonneville Dam } \\
\text { (average kcfs) }\end{array}$ & $\begin{array}{c}\text { Ives Island Staff } \\
\text { Gage 1 (ft) }\end{array}$ \\
\hline \hline November 22, 2004 & 126.7 & 0.88 \\
\hline November 23, 2004 & 125.5 & 1.0 \\
\hline November 24, 2004 & 170.0 & 3.7 \\
\hline December 8, 2004 & 151.8 & 3.4 \\
\hline December 9, 2004 & 102.8 & 1.6 \\
\hline
\end{tabular}

Table 3. Number of Fall Chinook Redds Found in Primary and Secondary Search Zones 2004

\begin{tabular}{||l|c|c||}
\hline \multicolumn{1}{|c|}{ Survey Date } & $\begin{array}{c}\text { Primary Zone (includes redds } \\
\text { found at lower Ives Island) }\end{array}$ & Secondary Zone \\
\hline \hline November 22 through 24 & 130 & 63 \\
\hline December 8 and 9 & 72 & 28 \\
\hline Total & 202 & 91 \\
\hline
\end{tabular}

The second deepwater fall Chinook salmon redd survey was completed on December 8 and 9, 2004. River discharge at Bonneville Dam during the survey period ranged from $151.8 \mathrm{kcfs}$ on December 8 and fell to $102.8 \mathrm{kcfs}$ on December 9; water turbidity averaged 3.4 NTU. A total of 100 additional redds were found, including 72 in the primary search zone and 28 in the secondary zone. The maximum depth at which redds could be detected was $8.5 \mathrm{~m}$ during both surveys.

The location of all redds $(n=293)$ found during surveys conducted in 2004 is shown in Figure 2. The MASS1 model was superimposed on the river layer to illustrate the redds in relation to water depth at a river flow of $125 \mathrm{kcfs}$ at Bonneville Dam. 


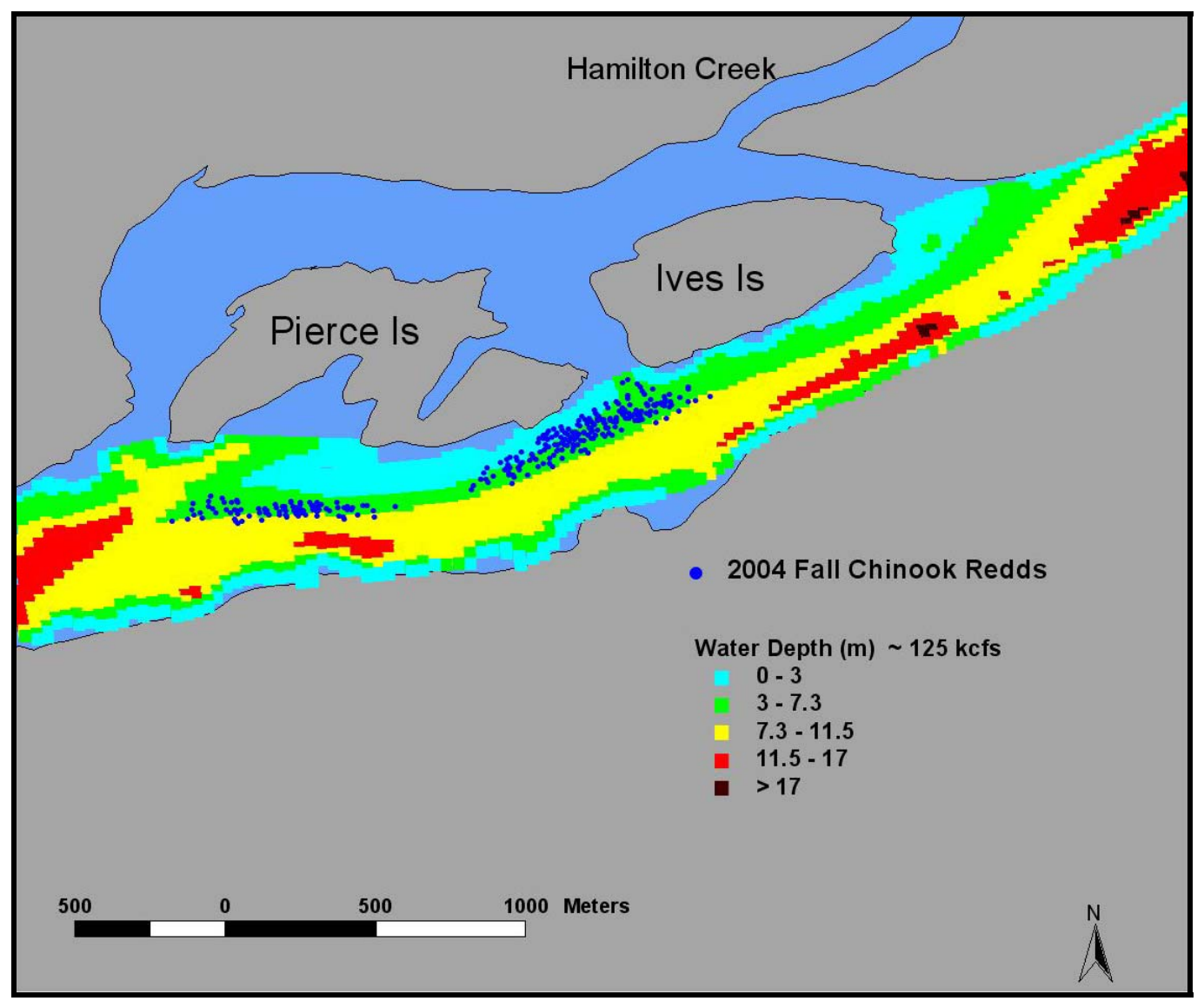

Figure 2. Location of Fall Chinook and Chum Salmon Redds $(n=293)$ in the Mainstem of the Columbia River Below Bonneville Dam in 2004

Water depths at redd locations ranged from 0.3 to $6.7 \mathrm{~m}$ (median $=3.0 \mathrm{~m}$ ) in the primary and 3.0 to $7.92 \mathrm{~m}$ (median $=4.8 \mathrm{~m}$ ) in the secondary zone at a river flow of approximately $123 \mathrm{kcfs}$ (Figure 3 ).

Dominant substrate measurements were measured from the majority of the redds found using the lasers for scaling. The long axis diameter from 120 redds found in the primary search zone ranged from 7.0 to $18 \mathrm{~cm}$ (median $=10.0 \mathrm{~cm}$ ) and 6.9 to $13.2 \mathrm{~cm}$ (median $=9.0 \mathrm{~cm}$ ) in the secondary zone $(\mathrm{n}=61)$. The substrate sizes were fairly uniform throughout the primary and secondary spawning zones and mostly fell into the medium cobble category (Figures 4 and 5). Only 16 redds were found in the gravel category and 2 in the large cobble category.

The Hamilton Slough survey was conducted on November 23, 2004. Low water elevation precluded surveys in the channel between Ives and Pierce Islands. A total of four carcasses were found, but no redds were observed. Additional chum or coho (O. kisutch) salmon carcasses were found at the mouth of Woodward Creek. We did not find any salmon redds during limited surveys at the mouths of Woodward, McCord, and Tanner Creeks. 


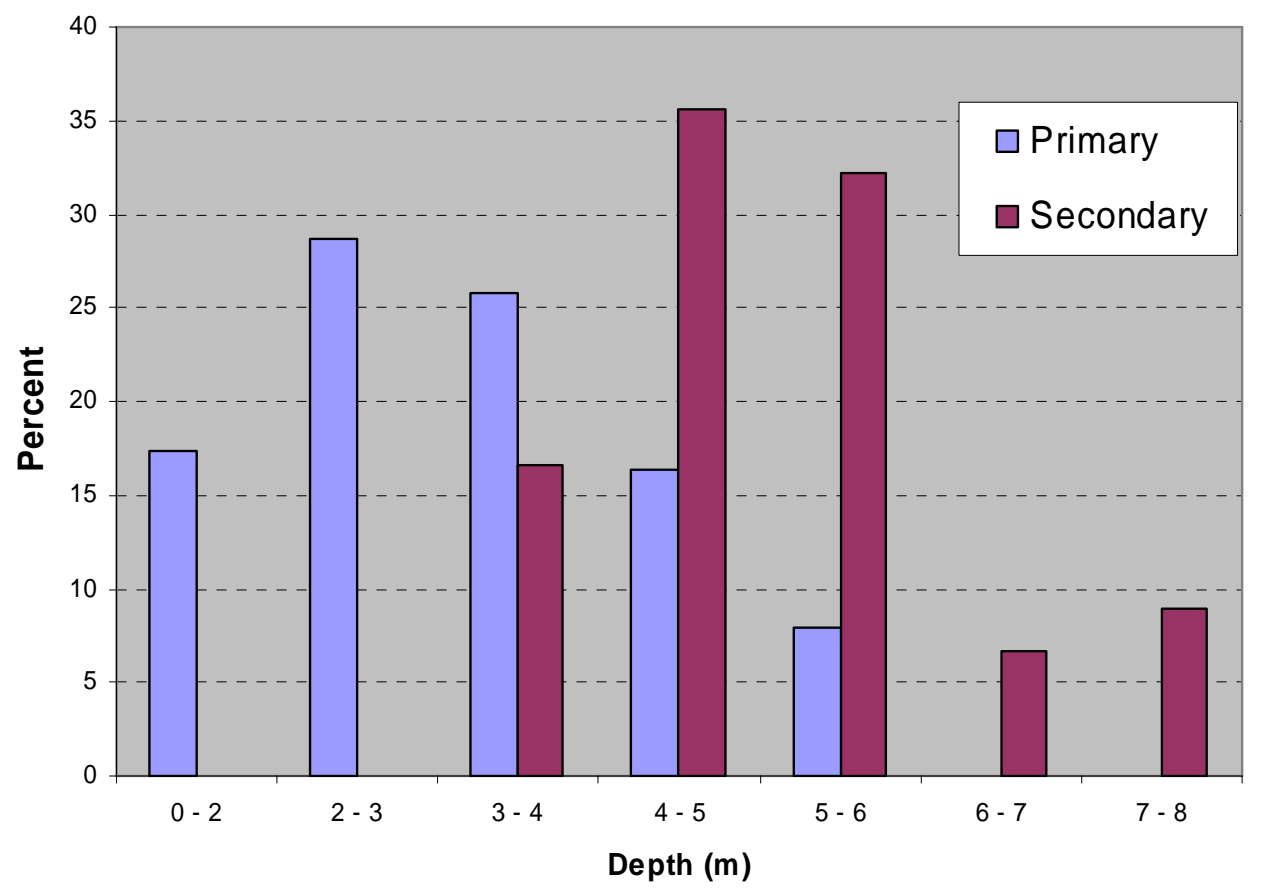

Figure 3. Distribution of Fall Chinook Salmon Redds $(n=292)$ Relative to Water Depth During the November and December 2004 Surveys in the Primary and Secondary Search Zones (flow approximately $123 \mathrm{kcfs}$ )

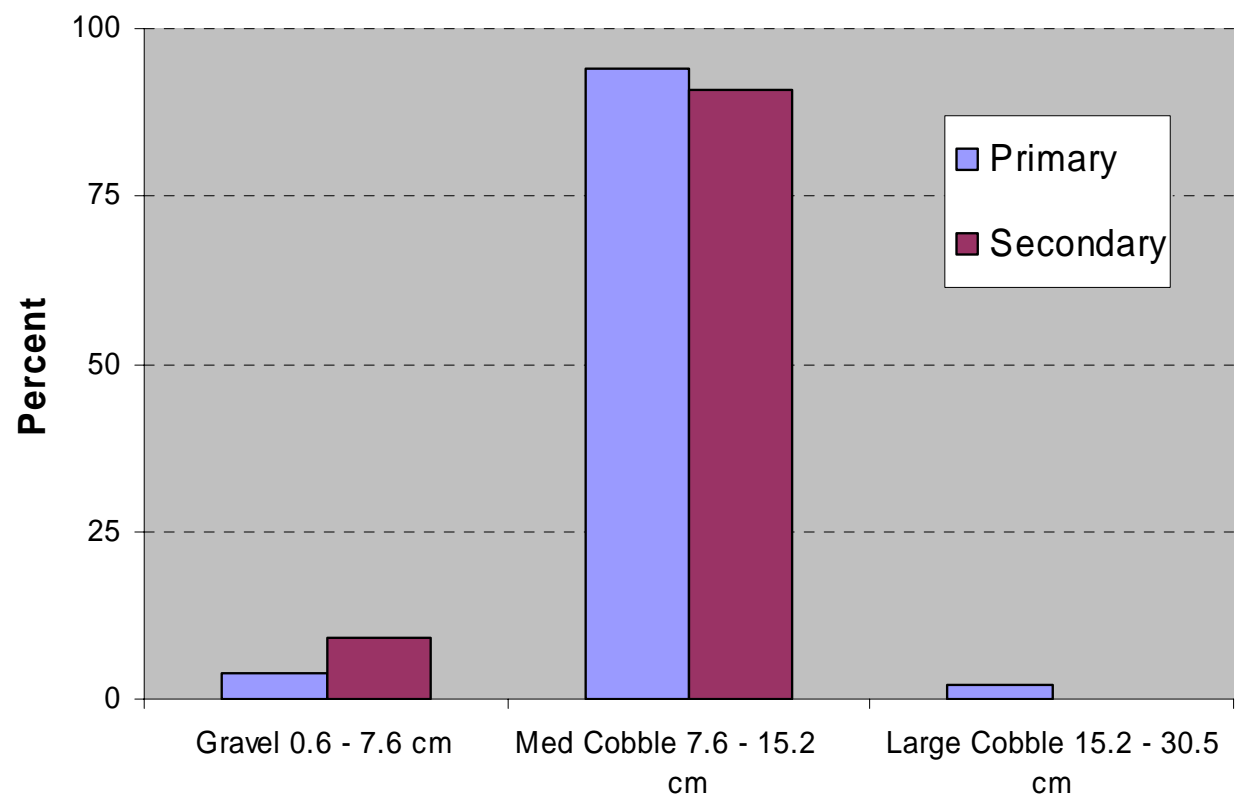

Figure 4. Dominant Substrate Classification of Fall Chinook Salmon Redds $(n=186)$ in the Primary and Secondary Search Zones 


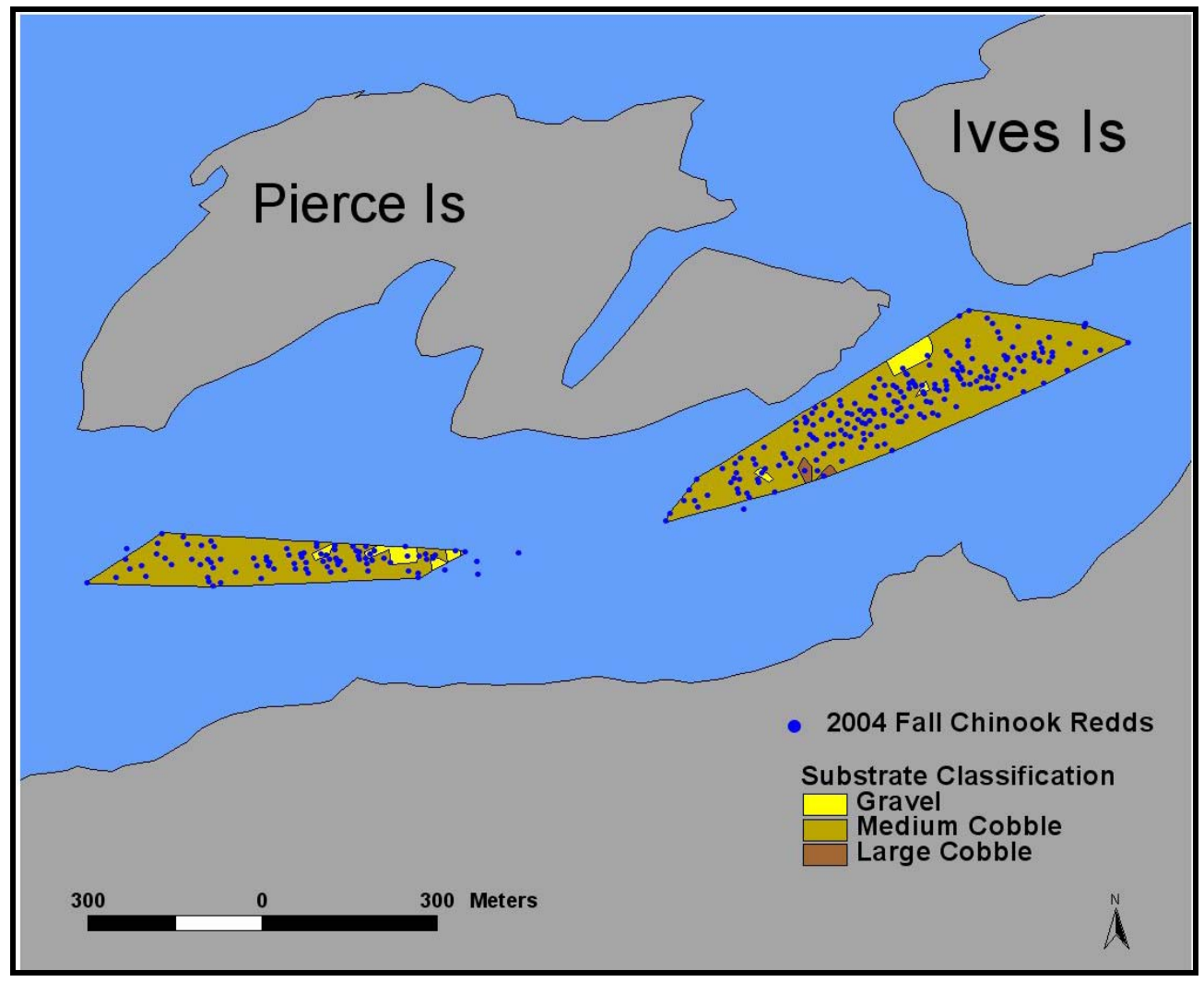

Figure 5. Substrate Composition Within the Fall Chinook Spawning Zones and Redds Found in 2004

The total area used by fall Chinook salmon for spawning was calculated by drawing a boundary line around the redd locations within the primary and secondary zones. A maximum convex polygon was created from points recorded above all salmon redds at both the upper and lower spawning areas. The radius of the polygon was then buffered $3 \mathrm{~m}$ to account for the redd areas that defined the polygon vertices. This buffer was then combined with the convex polygon, and the area was calculated. The area where redds were found encompassed 9.74 ha in the primary and 4.92 ha in the secondary zone (Figure 6). Additional maps showing how the spawning area has changed over the period from 1999 through 2004 are shown in Appendix B.

Near-bed water velocity readings were measured on December 9 at a river discharge of $105 \mathrm{kcfs}$. The water velocities ranged from 0.04 to $0.98 \mathrm{~m} / \mathrm{s}$ (median $0.45 \mathrm{~m} / \mathrm{s}$ ). The interpolated map shows the majority of the redds were found where velocities were $0.3 \mathrm{~m} / \mathrm{s}$ or greater. Velocities increased to near $1.0 \mathrm{~m} / \mathrm{s}$ along the southern part of this zone nearest the main river channel.

During the past 4 years of deepwater redd surveys by PNNL, a total population of spawning fish was estimated by extrapolating the redd count based on the portion of the area surveyed by video camera. The average vertical coverage along each transect line was estimated to be approximately $1.2 \mathrm{~m}$. This measurement was averaged during the two survey periods. Because the boat route varied somewhat along the line of each transect, the distance traveled along each transect varied. The actual redd count was used to estimate the total number of redds that may be present in the overall survey zone, assuming equal distribution throughout the two zones. Approximately $6.5 \%$ of the primary and $5.2 \%$ of the secondary zone were surveyed by the video camera. To estimate the total spawning population within the spawning 
zones (Figure 7), a multiplier of 3.4 adult fish for each redd was used (Visser 2000). Using this multiplier, approximately 10,800 fish were present during the peak spawning period in mid-November 2004 (Table 4).

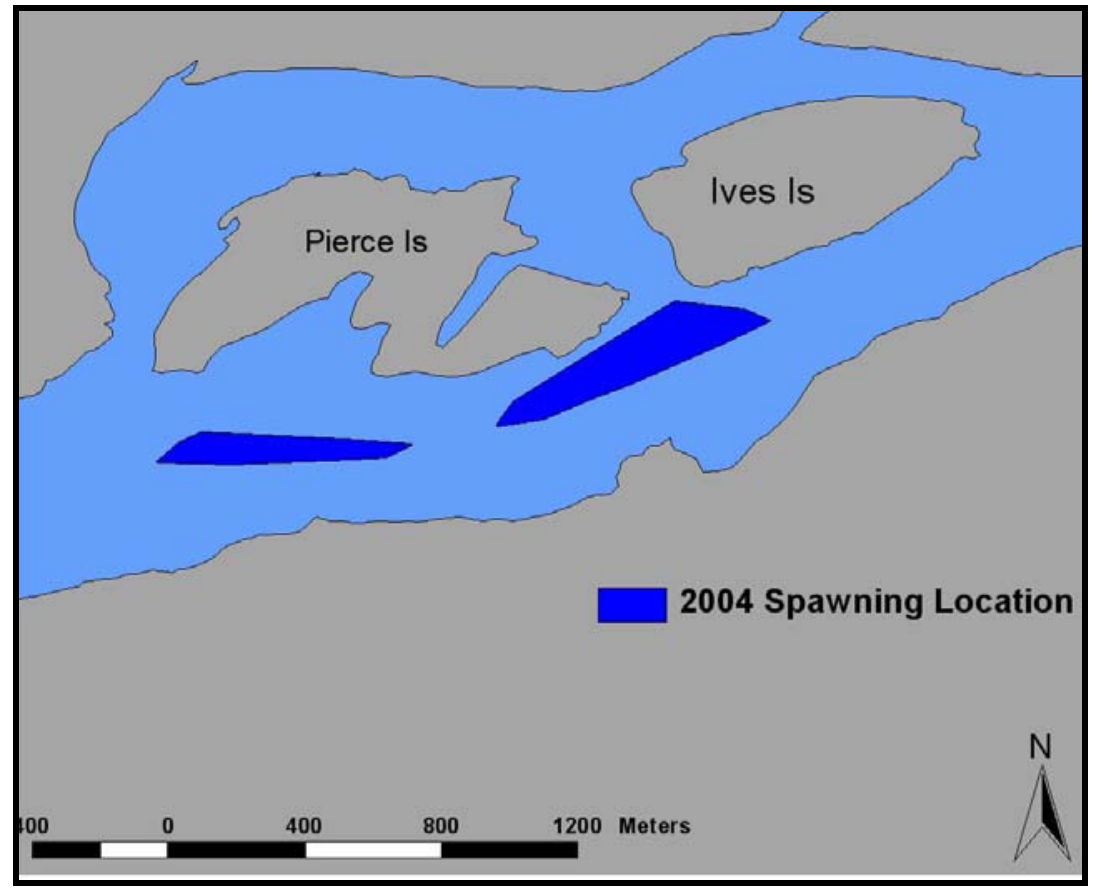

Figure 6. Fall Chinook Salmon Spawning Area for Redds Found During 2004

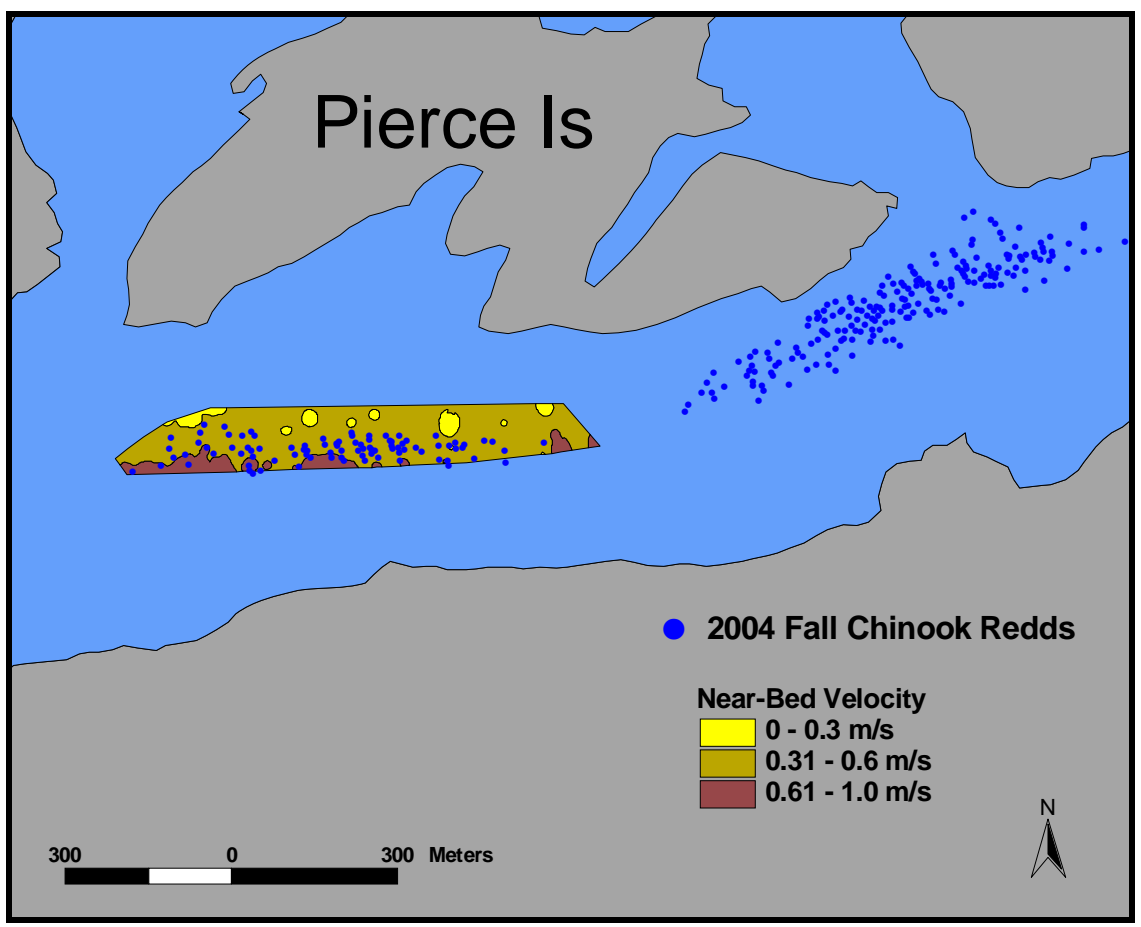

Figure 7. Near-Bed Water Velocity Measurements Taken December 9, 2004 (secondary zone) and Redd Locations (river flow approximately $105 \mathrm{kcfs}$ ) 
Table 4. Estimated Number of Fall Chinook Salmon Redds Occurring in the Primary Search and Secondary Zone near Ives and Pierce Islands near the Peak Spawning Period, November 22 and 23, 2004

\begin{tabular}{||l|c|c|c|c|c||}
\hline Location & $\begin{array}{c}\text { Total Area } \\
\text { Surveyed } \\
\left(\mathrm{m}^{2}\right)^{(\mathrm{a})}\end{array}$ & $\begin{array}{c}\text { Video Coverage } \\
(\%)\end{array}$ & $\begin{array}{c}\text { Number of } \\
\text { Redds Found }\end{array}$ & $\begin{array}{c}\text { Extrapolated Redd } \\
\text { Estimate }\end{array}$ & $\begin{array}{c}\text { Adult } \\
\text { Population } \\
\text { Estimate }\end{array}$ \\
\hline \hline Primary & 6,614 & 6.5 & 130 & 1,985 & 6,749 \\
\hline Secondary & 2,958 & 5.2 & 61 & 1,152 & 3,115 \\
\hline Total & 9,572 & & 191 & 3,137 & 9,864 \\
\hline
\end{tabular}

(a) Area encompassed the survey boat track and average transect length in each survey zone based on a $1.2-\mathrm{m}$ video field view along each transect.

In addition to the deepwater surveys conducted by PNNL during 2004, personnel from ODFW counted a total of 111 fall Chinook salmon redds on November 9 through 16, 2004, by wading or boat in water depths less than $2 \mathrm{~m}$. These redds were located at the upper part of Pierce Island and in the shallow channel between Ives and Pierce Islands (FPC 2004).

\subsection{Discussion}

A total of 293 fall Chinook salmon redds were found to occur near the vicinity of Ives and Pierce Islands downstream of Bonneville Dam in 2004. This number is slightly lower than the record number of redds found in 2003 when 336 redds were found. We continue to observe a larger portion of redds in the lower portion of Pierce Island (secondary zone) as the percentage of the total redds found increased from 3\% in 2000 to 31\% in 2004 (Figure 8). The overall spawning area was also the highest observed for 2004, growing from 4.0 ha in 1999 to 14.6 ha in 2004 (Table 5). No chum redds were found during our limited surveys. ODFW personnel documented chum spawning near the mouth of Hamilton Creek, one fall Chinook salmon in the slough area near the north river bank, and 37 redds in the channel between Ives and Pierce Islands.

The maximum water depths at which redds were detected during 2004 was $7.9 \mathrm{~m}$. At 3.4 NTU, water turbidity was higher than what we experienced during surveys in previous years. Ideal turbidity levels for visual detection would be in the 1- to 2-NTU range. Turbidity values exceeding 4 NTU can limit the ability to detect redds in water depths greater than $6 \mathrm{~m}$ (Dauble et al. 1999). Mean near-bed water velocity measurements within the suitable regions were generally on the very low end of the preferred criteria scale $(0.45 \mathrm{~m} / \mathrm{s})$. All redds mapped within the secondary zone were located in areas where water velocities exceeded $0.31 \mathrm{~m} / \mathrm{s}$. Groves and Chandler (1999) reported mean substrate level velocities of $0.88 \mathrm{~m} / \mathrm{s}$ on 164 fall Chinook redds below Hells Canyon Dam from 1993 through 1995. Water velocity measured near the bed within the secondary zone showed an increasing value toward the main river channel. River flows were consistent during the first survey period at approximately $126 \mathrm{kcfs}$ and varied from 151 to $102 \mathrm{kcfs}$ during the second survey. 


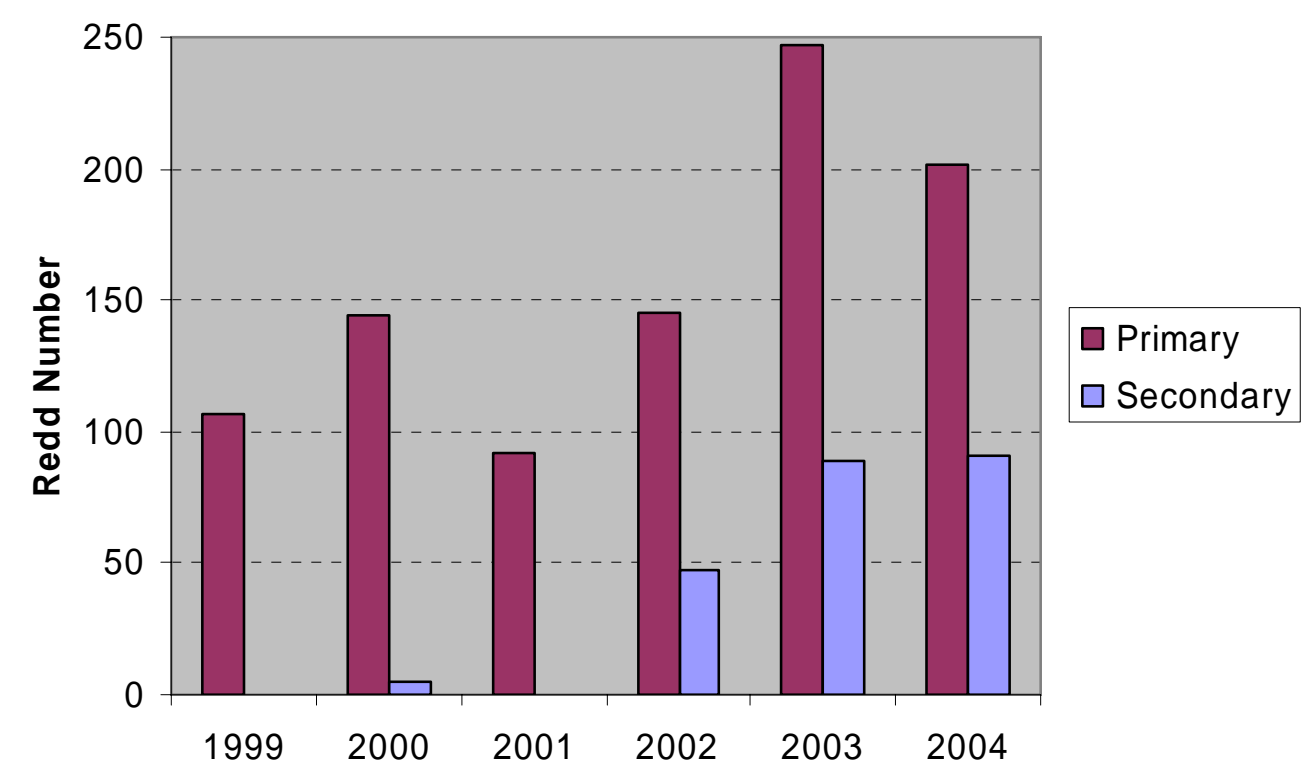

Figure 8. Historical Perspective of Redd Proportions in the Primary and Secondary Search Zones near Pierce Island, 2004

Table 5. Fall Chinook Redd Counts and Approximate Spawning Areas from 1999 Through 2004 near Ives and Pierce Islands

\begin{tabular}{||c|c|c||}
\hline \hline Year & $\begin{array}{c}\text { Redds } \\
\text { (n) }\end{array}$ & $\begin{array}{c}\text { Approximate Spawning } \\
\text { Area (ha) }\end{array}$ \\
\hline \hline 1999 & 64 & 4.0 \\
\hline 2000 & 76 & 6.3 \\
\hline 2001 & 43 & 4.9 \\
\hline 2002 & 192 & 9.3 \\
\hline 2003 & 336 & 13.7 \\
\hline 2004 & 293 & 14.6 \\
\hline
\end{tabular}




\subsection{References}

Burner CJ. 1951. “Characteristics of Spawning Nests of Columbia River Salmon.” Fishery Bulletin 61, Volume 52, U.S. Fish and Wildlife Service, Washington, D.C.

Chapman DW, DE Weitkamp, TL Welsh, and TH Schaldt. 1983. Effects of Minimum Flow Regimes on Fall Chinook Salmon Spawning at Vernita Bar 1978-1982. Don Chapman Consultants, McCall, Idaho, and Parametrix, Inc., Bellevue, Washington.

Dauble DD, RL Johnson, and AP Garcia. 1999. "Fall Chinook Salmon Spawning in the Tailraces of Lower Snake River Hydroelectric Projects.” Transactions of the American Fisheries Society 128:672-679.

FPC. 2004. Fish Passage Center, Portland, Oregon. Available at http://www.fpc.org/Index.html.

Groves P and J Chandler. 1999. "Spawning Habitat Use by Fall Chinook Salmon in the Snake River.” North American Journal of Fisheries Management 19:912-922.

Huntington C, W Nehlsen, and J Bowers. 1996. “A Survey of Healthy Native Stocks of Anadromous Salmonids in the Pacific Northwest and California.” Fisheries 21:6-14.

Hymer J. 1997. Results of Studies on Chinook Spawning in the Mainstem Columbia River Below Bonneville Dam. Columbia River Progress Report 97-9, Washington Department of Fish and Wildlife, Battle Ground, Washington.

Mueller RP. 2001. Deepwater Spawning of Fall Chinook Salmon (Oncorhynchus tshawytscha) Near Ives and Pierce Island of the Columbia River - Annual Report 2000. Bonneville Power Administration Project No. 1999-00304 (BPA Report DOE/BP-00000652-6).

Mueller RP. 2002. Deepwater Spawning of Fall Chinook Salmon (Oncorhynchus tshawytscha) Near Ives and Pierce Island of the Columbia River - Annual Report 2001. Bonneville Power Administration Project No. 1999-00304 (BPA Report DOE/BP-00000652-10).

Mueller RP. 2003. Deepwater Spawning of Fall Chinook Salmon (Oncorhynchus tshawytscha) Near Ives and Pierce Island of the Columbia River - Annual Report 2002. Bonneville Power Administration Project No. 1999-00301 (BPA Report DOE/BP-00000652-13).

Mueller RP. 2004. Deepwater Spawning of Fall Chinook Salmon (Oncorhynchus tshawytscha) Near Ives and Pierce Island of the Columbia River - Annual Report 2003. Bonneville Power Administration Project No. 1999-00301 (BPA Report DOE/BP-00000652-19).

Mueller RP and DD Dauble. 2000. Evidence of Deepwater Spawning of Fall Chinook Salmon (Oncorhynchus tshawytscha) Spawning Near Ives and Pierce Islands of the Columbia River - Annual Report 1999. Bonneville Power Administration Project No. 1999-00304 (BPA Report DOE/BP-00000652-2). 
Platts WS, WF Megahan, and GW Minshall. 1983. Methods for Evaluating Stream, Riparian, and Biotic Conditions. Technical Report INT-138, U.S. Forest Service, Washington, D.C.

U.S. Fish and Wildlife Service. 1999. "Endangered and Threatened Wildlife and Plants; Listing of Nine Evolutionarily Significant Units of Chinook Salmon, Chum Salmon, Sockeye Salmon, and Steelhead.” Federal Register 64:41835-41839.

van der Naald W, R Clark, R Brooks, and C Duff. 2004. Evaluation of Fall Chinook and Chum Salmon Spawning Below Bonneville Dam - Annual Report 2002-2003. Bonneville Power Administration Project No. 199900301 (BPA Report DOE/BP-00004028-3).

van der Naald W, C Duff, and R Brooks. 2005. Evaluation of Fall Chinook and Chum Salmon Spawning Below Bonneville Dam - Annual Report 2003-2004. Bonneville Power Administration Project No. 199900301 (BPA Report DOE/BP-00004028-4).

Visser RH. 2000. Utilizing Remotely Sensed Imagery and GIS to Monitor and Research Salmon Spawning: A Case Study of the Hanford Reach Fall Chinook (Oncorhynchus tshawytscha).

PNNL-13177, Pacific Northwest National Laboratory, Richland, Washington. 


\section{Appendix A}

\section{Near-Bed Water Velocity Point Measurements, 2004}




\section{Appendix A}

\section{Near-Bed Water Velocity Point Measurements, 2004}

Bed Velocity Coordinate Description

\begin{tabular}{||l|l||}
\hline \multicolumn{1}{|c|}{ Projection } & \multicolumn{1}{c|}{ Stateplane } \\
\hline \hline Zone & WA South 4602 \\
\hline Datum & NAD27 \\
\hline Units & US Survey feet \\
\hline
\end{tabular}

\begin{tabular}{||l|c|c|c|c||}
\hline No. & Northing & Easting & Depth $(\mathrm{m})$ & $\begin{array}{c}\text { Bed Velocity } \\
(\mathrm{m} / \mathrm{s})\end{array}$ \\
\hline \hline 1 & 107142.173 & 1614581.397 & 3.4 & 0.41 \\
\hline 2 & 107072.576 & 1614687.607 & 5.0 & 0.81 \\
\hline 3 & 107056.633 & 1614705.198 & 5.3 & 0.79 \\
\hline 4 & 107056.366 & 1614585.334 & 5.2 & 0.33 \\
\hline 5 & 107153.685 & 1614545.487 & 3.2 & 0.53 \\
\hline 6 & 107247.403 & 1614507.000 & 2.1 & 0.54 \\
\hline 7 & 107308.505 & 1614486.912 & 1.4 & 0.48 \\
\hline 8 & 107280.202 & 1614386.289 & 1.4 & 0.04 \\
\hline 9 & 107126.036 & 1614439.031 & 3.0 & 0.64 \\
\hline 10 & 107040.844 & 1614458.288 & 5.3 & 0.69 \\
\hline 11 & 107019.798 & 1614474.421 & 6.4 & 0.98 \\
\hline 12 & 107006.141 & 1614367.311 & 6.1 & 0.25 \\
\hline 13 & 107063.410 & 1614374.179 & 4.6 & 0.52 \\
\hline 14 & 107067.494 & 1614367.561 & 4.3 & 0.58 \\
\hline 15 & 107204.698 & 1614309.647 & 2.4 & 0.50 \\
\hline 16 & 107132.824 & 1614208.007 & 3.0 & 0.32 \\
\hline 17 & 107081.723 & 1614279.598 & 4.1 & 0.48 \\
\hline 18 & 107010.763 & 1614261.129 & 5.8 & 0.50 \\
\hline 19 & 106991.520 & 1614142.887 & 6.7 & 0.54 \\
\hline 20 & 107017.252 & 1614148.393 & 5.5 & 0.41 \\
\hline 21 & 107074.928 & 1614160.566 & 4.1 & 0.36 \\
\hline 22 & 107192.287 & 1614135.965 & 1.8 & 0.28 \\
\hline 23 & 107184.162 & 1614004.306 & 2.1 & 0.30 \\
\hline 24 & 107100.313 & 1614078.092 & 3.4 & 0.53 \\
\hline 25 & 107012.679 & 1614041.504 & 5.0 & 0.52 \\
\hline
\end{tabular}




\begin{tabular}{|c|c|c|c|c|}
\hline No. & Northing & Easting & Depth (m) & $\begin{array}{c}\text { Bed Velocity } \\
(\mathrm{m} / \mathrm{s})\end{array}$ \\
\hline 26 & 106976.179 & 1614036.650 & 6.1 & 0.36 \\
\hline 27 & 106996.882 & 1613989.175 & 6.6 & 0.50 \\
\hline 28 & 107050.626 & 1613973.056 & 4.6 & 0.51 \\
\hline 29 & 107137.692 & 1613977.545 & 3.0 & 0.32 \\
\hline 30 & 107102.877 & 1613874.221 & 3.4 & 0.32 \\
\hline 31 & 107051.632 & 1613918.252 & 4.3 & 0.45 \\
\hline 32 & 106999.520 & 1613926.514 & 5.8 & 0.32 \\
\hline 33 & 106960.039 & 1613913.719 & 7.0 & 0.43 \\
\hline 34 & 106970.891 & 1613811.448 & 6.4 & 0.38 \\
\hline 35 & 107053.401 & 1613815.297 & 5.2 & 0.30 \\
\hline 36 & 107046.601 & 1613822.610 & 4.4 & 0.28 \\
\hline 37 & 107159.098 & 1613808.252 & 3.0 & 0.18 \\
\hline 38 & 107065.277 & 1613778.912 & 4.1 & 0.30 \\
\hline 39 & 106998.575 & 1613765.985 & 5.6 & 0.49 \\
\hline 40 & 106967.136 & 1613783.094 & 6.1 & 0.65 \\
\hline 41 & 106963.131 & 1613699.319 & 0.0 & 0.38 \\
\hline 42 & 106995.687 & 1613703.906 & 5.6 & 0.41 \\
\hline 43 & 107071.183 & 1613707.971 & 4.3 & 0.35 \\
\hline 44 & 107161.812 & 1613667.987 & 2.9 & 0.38 \\
\hline 45 & 107136.812 & 1613560.530 & 3.4 & 0.31 \\
\hline 46 & 106976.871 & 1613656.600 & 6.1 & 0.49 \\
\hline 47 & 106991.494 & 1613586.236 & 5.9 & 0.52 \\
\hline 48 & 107160.752 & 1613488.330 & 2.7 & 0.31 \\
\hline 49 & 107139.594 & 1613453.294 & 2.7 & 0.42 \\
\hline 50 & 107060.646 & 1613512.972 & 4.7 & 0.35 \\
\hline 51 & 106957.242 & 1613547.093 & 6.7 & 0.72 \\
\hline 52 & 106945.170 & 1613497.069 & 6.7 & 0.55 \\
\hline 53 & 107019.987 & 1613474.782 & 5.6 & 0.38 \\
\hline 54 & 107071.626 & 1613455.280 & 4.3 & 0.41 \\
\hline 55 & 107236.759 & 1613373.091 & 2.1 & 0.28 \\
\hline 56 & 106930.539 & 1613383.867 & 7.0 & 0.65 \\
\hline 57 & 106934.197 & 1613340.188 & 6.7 & 0.59 \\
\hline 58 & 107190.012 & 1613229.959 & 3.4 & 0.27 \\
\hline 59 & 107181.734 & 1613099.487 & 3.8 & 0.38 \\
\hline 60 & 107090.968 & 1613165.019 & 4.3 & 0.49 \\
\hline 61 & 107000.693 & 1613207.738 & 5.8 & 0.54 \\
\hline 62 & 106942.117 & 1613189.863 & 6.9 & 0.75 \\
\hline
\end{tabular}




\begin{tabular}{|c|c|c|c|c|}
\hline No. & Northing & Easting & Depth (m) & $\begin{array}{c}\text { Bed Velocity } \\
(\mathrm{m} / \mathrm{s})\end{array}$ \\
\hline 63 & 106969.179 & 1613110.905 & 6.4 & 0.70 \\
\hline 64 & 107126.203 & 1613076.430 & 5.0 & 0.54 \\
\hline 65 & 107126.542 & 1613077.411 & 4.4 & 0.20 \\
\hline 66 & 107208.891 & 1612994.995 & 3.4 & 0.21 \\
\hline 67 & 107196.121 & 1612853.221 & 3.5 & 0.33 \\
\hline 68 & 107071.211 & 1612950.669 & 5.2 & 0.52 \\
\hline 69 & 106941.481 & 1612999.982 & 7.0 & 0.83 \\
\hline 70 & 106925.917 & 1612900.867 & 7.0 & 0.62 \\
\hline 71 & 106992.027 & 1612882.550 & 6.4 & 0.41 \\
\hline 72 & 107150.016 & 1612847.649 & 4.3 & 0.25 \\
\hline 73 & 107238.962 & 1612793.333 & 3.0 & 0.37 \\
\hline 74 & 107243.421 & 1612603.978 & 2.7 & 0.32 \\
\hline 75 & 107162.025 & 1612692.624 & 3.8 & 0.37 \\
\hline 76 & 107042.659 & 1612772.954 & 5.5 & 0.35 \\
\hline 77 & 106985.858 & 1612805.807 & 6.1 & 0.39 \\
\hline 78 & 106949.220 & 1612740.842 & 7.0 & 0.65 \\
\hline 79 & 107254.697 & 1612584.944 & 3.0 & 0.39 \\
\hline 80 & 107274.869 & 1612460.092 & 3.5 & 0.27 \\
\hline 81 & 107171.242 & 1612539.561 & 3.2 & 0.45 \\
\hline 82 & 107021.000 & 1612627.426 & 5.6 & 0.44 \\
\hline 83 & 106963.958 & 1612636.390 & 6.4 & 0.71 \\
\hline 84 & 107027.255 & 1612534.087 & 5.6 & 0.56 \\
\hline 85 & 107115.241 & 1612547.847 & 4.0 & 0.37 \\
\hline 86 & 107284.616 & 1612399.415 & 4.0 & 0.26 \\
\hline 87 & 107203.436 & 1612330.838 & 3.8 & 0.29 \\
\hline 88 & 107137.953 & 1612382.578 & 4.1 & 0.37 \\
\hline 89 & 107047.439 & 1612424.547 & 5.2 & 0.37 \\
\hline 90 & 106982.622 & 1612477.830 & 6.2 & 0.65 \\
\hline 91 & 106915.787 & 1612464.982 & 7.6 & 0.68 \\
\hline 92 & 106979.217 & 1612425.647 & 6.4 & 0.61 \\
\hline 93 & 107040.646 & 1612376.735 & 5.0 & 0.70 \\
\hline 94 & 107128.625 & 1612347.534 & 3.5 & 0.48 \\
\hline 95 & 107198.545 & 1612291.420 & 4.3 & 0.19 \\
\hline 96 & 107194.986 & 1612235.313 & 4.6 & 0.22 \\
\hline 97 & 107202.315 & 1612142.726 & 5.5 & 0.20 \\
\hline 98 & 107113.939 & 1612193.670 & 4.6 & 0.43 \\
\hline 99 & 107096.020 & 1612243.684 & 4.1 & 0.46 \\
\hline
\end{tabular}




\begin{tabular}{||c|c|c|c|c||}
\hline No. & Northing & Easting & Depth $(\mathrm{m})$ & $\begin{array}{c}\text { Bed Velocity } \\
(\mathrm{m} / \mathrm{s})\end{array}$ \\
\hline \hline 100 & 106968.824 & 1612251.065 & 5.5 & 0.60 \\
\hline 101 & 106936.828 & 1612254.261 & 6.7 & 0.77 \\
\hline 102 & 106926.741 & 1612184.106 & 7.3 & 0.76 \\
\hline 103 & 106965.444 & 1612152.831 & 5.6 & 0.50 \\
\hline 104 & 107018.400 & 1612165.440 & 5.0 & 0.58 \\
\hline 105 & 107093.801 & 1612164.160 & 4.6 & 0.56 \\
\hline 106 & 107103.851 & 1612167.730 & 4.6 & 0.59 \\
\hline 107 & 107104.218 & 1612119.999 & 5.0 & 0.41 \\
\hline 108 & 107111.960 & 1612005.709 & 6.1 & 0.30 \\
\hline 109 & 107050.874 & 1612050.554 & 5.6 & 0.46 \\
\hline 110 & 107017.878 & 1612094.738 & 5.2 & 0.42 \\
\hline 111 & 106916.792 & 1612106.337 & 7.0 & 0.72 \\
\hline 112 & 106899.699 & 1612022.021 & 7.9 & 0.78 \\
\hline 113 & 106940.653 & 1612010.695 & 6.4 & 0.70 \\
\hline 114 & 106994.634 & 1611999.311 & 5.2 & 0.50 \\
\hline 115 & 107055.265 & 1611991.594 & 5.8 & 0.42 \\
\hline 116 & 107044.178 & 1611911.143 & 6.7 & 0.32 \\
\hline 117 & 106971.474 & 1611911.407 & 5.8 & 0.56 \\
\hline 118 & 106943.881 & 1611905.322 & 6.2 & 0.67 \\
\hline 119 & 106886.417 & 1611904.144 & 7.3 & 0.88 \\
\hline 120 & 106983.321 & 1611838.557 & 6.6 & 0.51 \\
\hline
\end{tabular}




\section{Appendix B}

Maps Illustrating Fall Chinook Salmon Redd Spawning Areas, 1999 Through 2003 


\section{Appendix B}

\section{Maps Illustrating Fall Chinook Salmon Redd Spawning Areas, 1999 Through 2003}
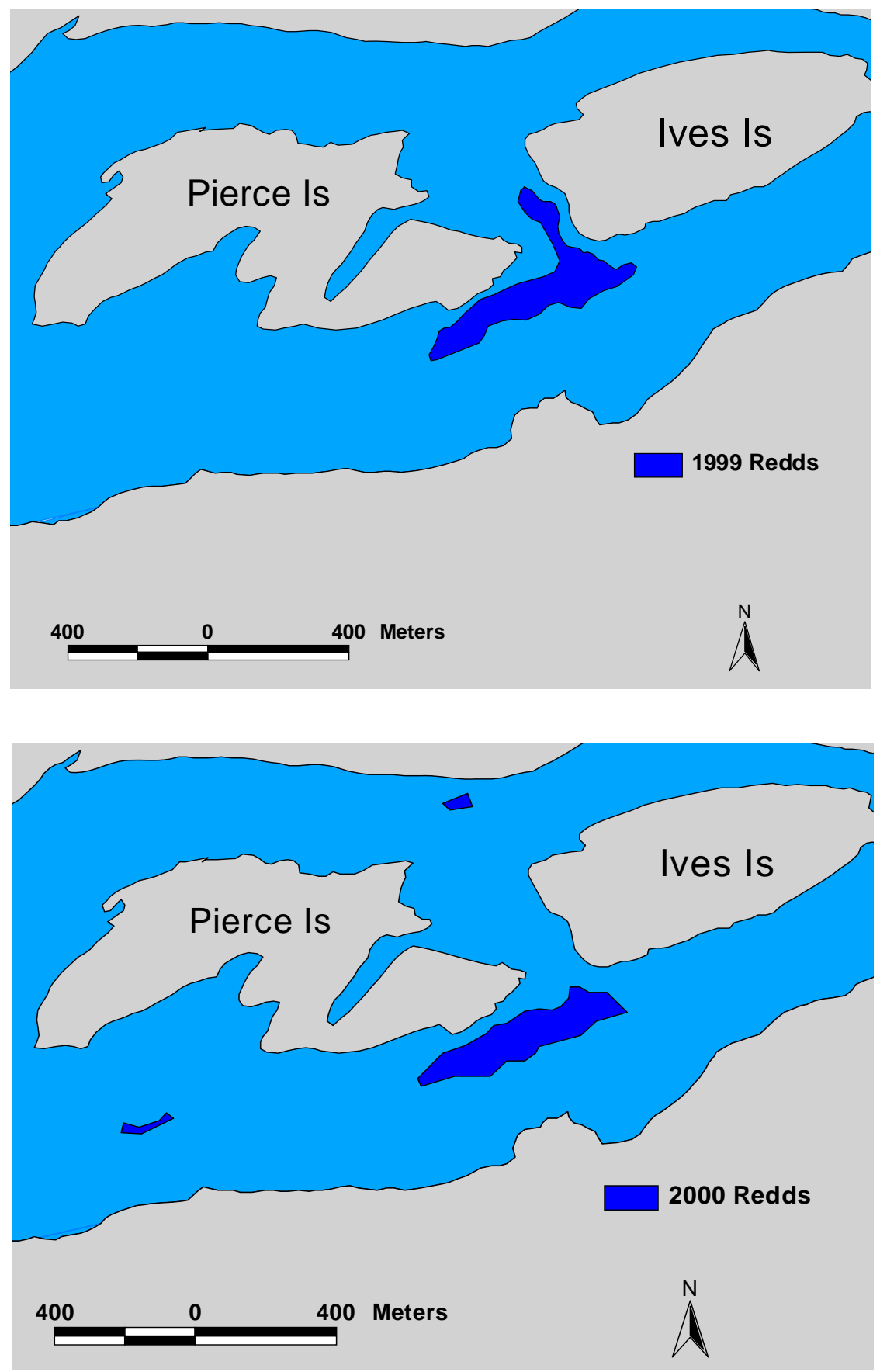

B.1 

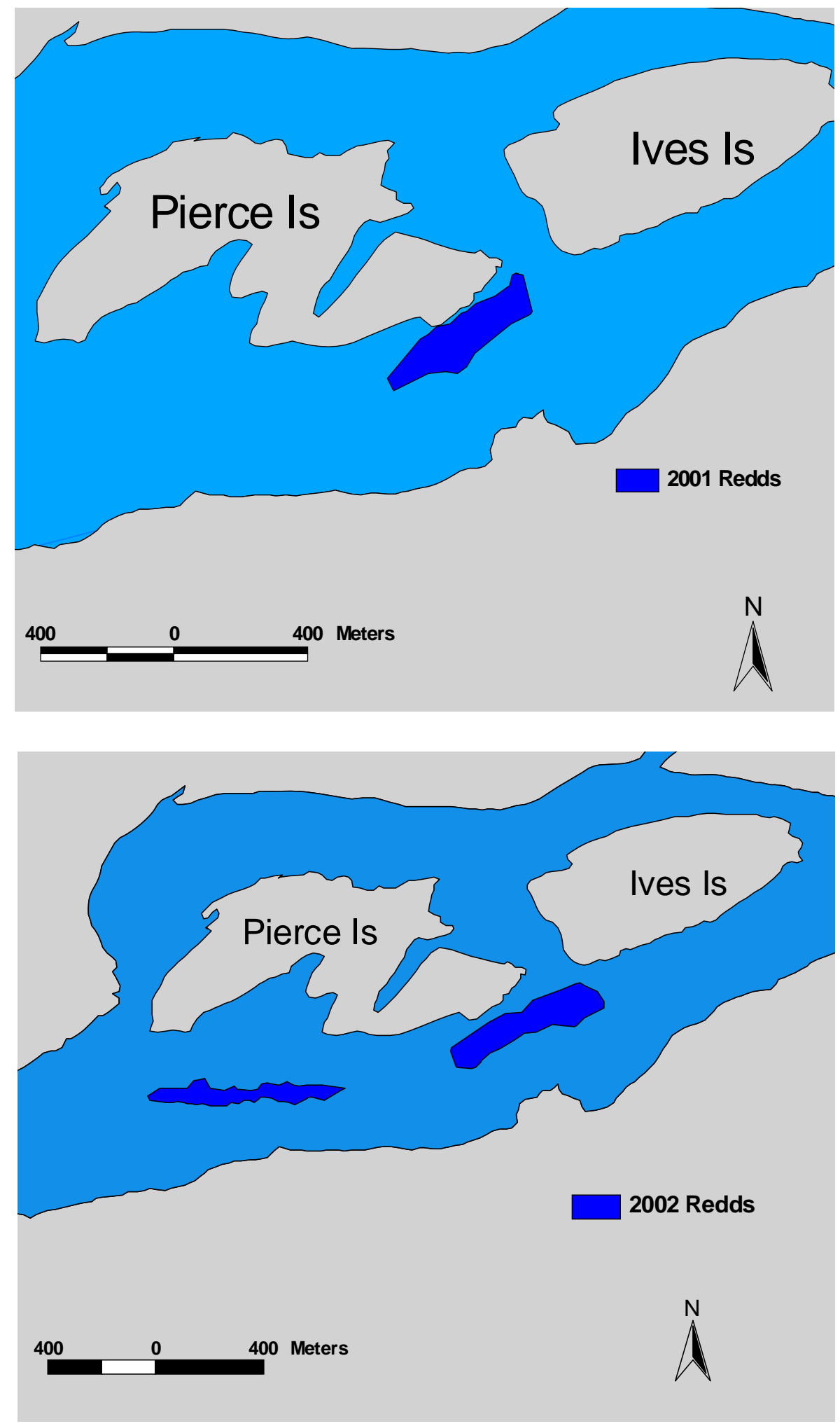